
RESEARCH AND DEVELOPMENT

\title{
Faktor Individu, Paparan Debu, dan CO dengan Gambaran Faal Paru Petugas SPBU
}

\author{
Diah Indriyani Novitasari ${ }^{1 凶}$, Yuni Wijayanti ${ }^{1}$ \\ ${ }^{1}$ Jurusan Ilmu Kesehatan Masyarakat, Fakultas Ilmu Keolahragaan, Universitas Negeri Semarang, Indonesia
}

\begin{tabular}{l} 
Info Artikel \\
\hline Sejarah Artikel: \\
Diterima 19 Juni 2018 \\
Disetujui 16 Okber 2018 \\
Dipublikasikan 30 \\
Oktober 2018 \\
\hline Keywords: \\
Air Pollution, Motor Vehi- \\
cle, Lung Function, Gas \\
Station Officer \\
\hline DOI: \\
https://doi.org/10.15294 \\
/higeia.v2i4.23617
\end{tabular}

\begin{abstract}
Abstrak
Tujuh puluh persen pencemaran udara berasal dari emisi kendaraan bermotor. Efek dari emisi kendaraan bermotor dapat mengganggu fungsi paru-paru salah satunya petugas SPBU. Penelitian ini dilakukan di dua SPBU yang berada di ruas jalan dengan volume kendaraan tertinggi pada tahun 2018 yang bertujuan untuk mengetahui hubungan antara faktor individu, paparan debu, dan CO dengan gambaran faal paru. Jenis penelitian ini adalah observasional analitik dengan rancangan cross sectional. Sampel penelitian ini adalah 34 petugas SPBU dengan teknik total sampling. Data dianalisis menggunakan uji Chi-square dan uji Mann Whitney. Hasil menunjukkan ada hubungan antara jenis kelamin $(p=0,035)$, masa kerja $(p=0,017)$, dan kebiasaan merokok $(p=0,023)$ dengan gambaran faal paru. Sedangkan, variabel umur, lama paparan, penggunaan APD, status gizi, riwayat penyakit, paparan debu, dan $\mathrm{CO}$ tidak berhubungan dengan gambaran faal paru. Simpulan penelitian ini yaitu jenis kelamin, masa kerja, dan kebiasaan merokok berhubungan dengan gambaran faal paru pada petugas SPBU. Disarankan untuk menggunakan APD ketika bekerja serta mengurangi perilaku merokok.
\end{abstract}

\begin{abstract}
Seventy percent of air pollutions comes from motor vehicle emissions. The effects of the emissions can interfere the lung function, especially for the gas station officers. This study was conducted at two gas station located in road with highest vehicle volume in 2018 which to know the relation between individual factor, dust exposure, and $\mathrm{CO}$ with the lung function. The type of this study was analytic observational with cross sectional design. The sample was 34 gas station officers with total sampling technique. Data were analyzed using Chi-square and Mann Whitney test. The results showed there were related between sex $(p=0,035)$, length of work $(p=$ $0,017)$, and smoking habit $(p=0,023)$ with lung function. Age, long exposure, usage of personal safety, nutritional status, history of disease, dust exposure, and $\mathrm{CO}$ not related with lung function. The conclusions were gender, length of work, and smoking habits related with the lung function at the gas station officer. It's recommended to use personal safety when working and reduce smoking behavior.
\end{abstract}




\section{PENDAHULUAN}

Menurut World Health Organization (2016) 7,3 juta orang meninggal akibat pencemaran udara dan kasus tertinggi terjadi di kawasan Timur Tengah dan Asia Tenggara dengan ratarata tingkat pencemaran per tahun melebihi nilai ambang batas. Tercatat 3,8 juta kematian di kawasan Timur Tengah dan Asia Tenggara dimana 567.000 kasus kematian diantaranya disebabkan oleh penyakit pernapasan dan kanker yang diakibatkan oleh paparan partikel halus $\left(\mathrm{PM}_{2,5}\right)$. Menurut hasil penelitian yang dilakukan di Sao Pualo, Brazil tentang hubungan antara polusi lalu lintas dengan kapasitas vital paru menunjukkan bahwa pekerja dengan paparan $\mathrm{PM}_{2,5}$ lebih dari 36,6 $\mu \mathrm{g} / \mathrm{m}^{3}$ menunjukkan penurunan kapasitas vital paru dengan $p$ value sebesar 0,076 (Santos, 2016).

Kasus pencemaran udara di perkotaan $70 \%$ diantaranya disebabkan oleh emisi kendaraan bermotor. Menurut data perkembangan jumlah kendaraan bermotor dari Badan Pusat Statistik (BPS) menunjukkan bahwa jumlah kendaraan bermotor di Indonesia sebanyak 129.281.079 dengan sekitar $81 \%$ diantaranya merupakan jenis sepeda motor. Tahun 2016 di Indonesia kasus kematian akibat polusi udara meningkat menjadi 61 ribu orang atau rata-rata 25 orang meninggal per 100 ribu kapita dibandingkan tahun sebelumnya sebesar 50.000 jiwa.

Menurut data Indeks Kualitas Udara tingkat provinsi tahun 2011-2015 menunjukkan bahwa provinsi Jawa Tengah menempati peringkat 2 dengan tingkat pencemaran udara tertinggi di pulau Jawa. Rata-rata indeks kualitas udara di Jawa Tengah sebesar 80,79 dimana termasuk ke kategori sedang. Menurut data pemantauan udara ambien di Kabupaten Semarang selama 3 tahun terakhir kadar debu total telah melebihi nilai ambang batas sebesar $90 \mu \mathrm{g} / \mathrm{Nm}^{3}$. Pada tahun 2015 kadar debu total sebesar $242 \mu \mathrm{g} / \mathrm{Nm}^{3}$, kemudian pada tahun 2016 sebesar $207,1 \mu \mathrm{g} / \mathrm{Nm}^{3}$, dan pada tahun 2017 sebesar $251,4 \mu \mathrm{g} / \mathrm{Nm}^{3}$. Sedangkan pada parameter CO selama 3 tahun terakhir masih dibawah nilai ambang batas sebesar 15.000 $\mu \mathrm{g} / \mathrm{Nm}^{3}$ namun kadar $\mathrm{CO}$ terus meningkat dari tahun ke tahun. Kadar CO pada tahun 2015 sebesar $1483 \mu \mathrm{g} / \mathrm{Nm}^{3}$ kemudian pada tahun 2016 meningkat menjadi $1802,3 \mu \mathrm{g} / \mathrm{Nm}^{3}$, dan pada tahun 2017 mengalami peningkatan yang signifikan menjadi $7125 \mu \mathrm{g} / \mathrm{Nm}^{3}$.

Debu (dust) adalah partikel padat yang terjadi karena proses mekanis (pemecahan dan reduksi) terhadap masa padat, dimana partikel itu masih dipengaruhi oleh gravitasi. Debu yang berasal dari arus lalu lintas kendaraan dapat mempengaruhi fungsi paru karena memiliki tingkat toksisitas paling tinggi dibandingkan jenis polutan udara lainnya. Gejala yang sering ditimbulkan akibat paparan debu dapat berupa batuk dan sesak napas yang dapat menurunkan fungsi paru. Menurut penelitian Lippmann (2009) menunjukkan bahwa ada peningkatan keluhan sesak napas sebesar $10 \%$ yang disebabkan oleh paparan debu dari kendaraan bermotor

Debu sering dijadikan indikator pencemaran yang digunakan untuk menunjukkan tingkat bahaya baik di lingkungan maupun terhadap kesehatan dan keselamatan kerja. Efek debu terhadap kesehatan bergantung kepada solubility, komposisi kimia, konsentrasi debu, dan ukuran partikel debu. Paparan debu dapat menimbulkan pembatasan aliran udara (enyakit obstrukstif), penebalan dinding bronki, meningkatkan sekresi mukus, merendahkan ambang refleks penyempitan dan batuk, meningkatkan kerentanan terhadap infeksi pernapasan dan gejala asmatik (Suyono, 1995).

Karbon monoksida (CO) adalah suatu gas yang tidak berwarna, tidak berbau dan juga tidak berasa. Gas CO sebagian besar berasal dari pembakaran bahan bakar fosil dengan udara yang berupa gas buangan. Emisi kendaraan bermotor menyumbang hampir 70,5 $\%$ karbon monoksida (CO) yang akan memberikan efek yang buruk terutama terhadap sistem pernapasan. Kota besar yang padat lalu lintas akan banyak menghasilkan gas $\mathrm{CO}$ sehingga kadar CO relatf tinggi (Wardhana, 2004). Menurut penelitian Obaseki (2014) tentang gejala pernapasan, fungsi paru, dan 
hembusan CO pada pekerja lalu lintas di Nigeria menunjukkan seseorang yang bekerja di lokasi lalu lintas memiliki tingkat hembusan $\mathrm{CO}$ yang tinggi $(p=0,006)$ serta menunjukkan gejala berupa batuk $(p=0,750)$ dan sesak napas $(p=0,566)$ yang diakibatkan oleh polutan di udara.

Setiap 5 liter bensin dapat menghasilkan 1-1,5 kg CO yang dapat mencemari udara. Hemoglobin yang biasanya membawa oksigen dan udara lebih tertarik dengan CO daripada oksigen dan akan membentuk ikatan kimia yang lebih kuat. Setelah paparan terjadi untuk beberapa jam kemudian hemoglobin tidak mampu lagi mengikat oksigen yang diperlukan tubuh. Jika kita duduk di udara dengan kadar 60 bpj CO selama 8 jam, maka kemampuan mengikat oksigen oleh darah turun sebanyak 15 $\%$ yang sama dengan kehilangan darah sebanyak 0,5 liter.(Sastrawijaya, 2009).

Gangguan fungsi paru adalah gangguan paru berupa ketidakmampuan pengembangan (elastisitas) parunya maupun gangguan saluran napas baik struktural (anatomis) maupun fungsional yang menyebabkan perlambatan aliran udara respirasi (Epler. G. R dalam Yuliawati, 2015). Menurut penelitian Aulia (2010) tentang faktor-faktor yang berhubungan dengan kapasitas vital paru pada operator SPBU 24.301.118 di Palembang menyatakan bahwa kapasitas vital paru dipengaruhi oleh faktor intrinsik berupa umur, jenis kemalin, masa kerja, status gizi, kebiasaan merokok, kebiasaan olahraga, riwayat pekerjaan, dan riwayat penyakit. Faktor intrinsik yang berhubungan dengan kapasitas vital paru pada penelitian tersebut antara lain umur $(p=0,036)$, jenis kelamin $(p=0,017)$, dan masa kerja $(p=0,045)$. Hasil penelitian Dase (2013) tentang faktorfaktor yang berhubungan dengan kapasitas paru karyawan SPBU di Makassar berupa umur, masa kerja, kebiasaan merokok, lama kerja, dan status gizi menunjukkan bahwa ada hubungan antara umur $(p=0,015)$, masa kerja $(p=0,019)$, dan kebiasaan merokok $(p=0,019)$ dengan gangguan kapasitas paru pada karyawan SPBU. Penelitian serupa yang dilakukan oleh Laga (2013) menunjukkan bahwa ada hubungan antara umur $(p=0,018)$, masa kerja $(p=0,013)$, kebiasaan merokok $(p=0,037)$, dan tidak menggunakan APD $(p=0,018)$ dengan kapasitas vital paru.

Penelitian ini dilakukan di SPBU 44505 02 dan SPBU 4450508 di Kabupaten Semarang dan berada di jalan arteri Semarang-Solo dan Semarang-Yogyakarta. Kedua SPBU tersebut berada di ruas jalan Diponegoro yang memiliki volume kendaraan tertinggi dibandingkan ruas jalan lainnya yaitu sebesar 1.611 unit per jam. Tingginya volume kendaraan pada ruas jalan tersebut akan berkontribusi terhadap peningkatan pencemaran udara akibat emisi kendaraan bermotor dan jenis kendaraan yang melewati ruas jalan tersebut lebih beragam seperti mobil, motor, angkutan umum, bus, dan truk dimana jenis kendaraan juga berperan dalam menentukan jumlah emisi yang dihasilkan. Menurut penelitian Anggarani (2016) tentang hubungan kepadatan lalu lintas dengan konsentrasi $\mathrm{COHb}$ di sepanjang jalan nasional kota Semarang menunjukkan bahwa ada hubungan antara kepadatan lalu lintas dengan konsentrasi CO $(p=0,0001)$ dan kepadatan lalu lintas dengan konsentrasi $\mathrm{COHb}$ $(p=0,0001)$.

Hasil studi pendahuluan yang dilakukan pada tanggal 17 Januari 2018 pada petugas SPBU di Kabupaten Semarang menunjukkan bahwa 6 dari 10 responden yang diwawancara merasakan keluhan gangguan pernapasan berupa batuk dan sesak napas. Selain itu dari hasil pengukuran spirometri menunjukkan bahwa ke enam responden tersebut memiliki gambaran faal paru yang tidak normal dengan nilai kapasitas vital paru $<50 \%$. Berdasarkan permasalahan yang telah dipaparkan, penelitian ini bertujuan untuk mengetahui hubungan antara faktor individu, paparan debu, karbon monoksida (CO), serta faktor yang paling berhubungan dengan gambaran faal paru pada petugas SPBU.

\section{METODE}

Jenis penelitian yang digunakan adalah observasional nalitik dengan rancangan atau 
desain penelitian cross sectional. Variabel bebas dalam penelitian ini adalah faktor individu berupa umur, jenis kelamin, masa kerja, lama paparan, kebiasaan merokok, penggunaan APD, status gizi, dan riwayat penyakit. Variabel bebas lainnya yang digunakan dalam penelitian ini adalah paparan debu dan paparan karbon monoksida. Sedangkan untuk variabel terikat dalam penelitian ini adalah gambaran faal paru pada petugas SPBU. Kemudian untuk mengetahui hubungan antara variabel bebas dan variabel terikat digunakan uji bivariat dengan uji statistik chi-square untuk skala data kategorik dengan syarat bahwa nilai expected satu sel tidak lebih dari $20 \%$ dengan uji alternatif dari uji Chi-square adalah uji Fisher Exact Test. Untuk data dengan skala data numerik digunakan uji Independent $T$ Test dengan syarat data terdistribusi normal dengan uji alternatifnya adalah uji Mann Whietney. Kemudian untuk mengetahui variabel yang paling berhubungan dengan variabel terikat dilakukan analisis multivariat menggunakan uji statistik Regresi Logistik karena skala data variabel terikat adalah kategorik.

Populasi adalah sekelompok individu yang mempunyai karakteristik yang sama, yaitu seperti sekelomok masyarakat yang memiliki umur, status sosial, seks, pekerjaan yang sama, atau objek lain yang mempunyai karakteristik yang sama. Populasi dalam penelitian ini adalah seluruh petugas SPBU yang bekerja di wilayah SPBU 4450502 dan SPBU 4450508 di ruas jalan Diponegoro Kabupaten Semarang yang berjumlah 50 orang.

Sampel adalah bagian dari jumlah populasi yang dimiliki oleh populasi. Teknik pengambilan sampel pada penelitian ini adalah total sampling. Jumlah sampel pada penelitian ini didasarkan perhitungan Lemeshow rumus pengambilan besar sampel. Jumlah sampel minimal dalam penelitian ini adalah 34 sampel. Pengambilan sampel dalam penelitian ini yaitu dengan mengambil semua petugas yang bekerja pada shift kerja pagi dan siang yang berjumalah 17 petugas pada satu lokasi SPBU.

Sumber data dalam penelitian ini adalah data primer. Terdapat dua jenis data primer dalam penelitian ini yaitu data primer mengenai kondisi lingkungan dan petugas SPBU. Pertama kondisi lingkungan berisi hasil pengukuran kadar debu total dan kadar karbon monoksida di lokasi SPBU. Kedua, petugas SPBU yang berisi hasil wawancara langsung dengan responden pada seluruh sampel penelitian. Kemudian hasil pengukuran spirometri yang dilakukan kepada responden penelitian dengan pengukuran yang dilakukan oleh petugas laboratorium.

Instrumen yang digunakan pada penelitian ini meliputi alat untuk mengukur variable terikat (gambaran faal paru) dan variabel bebas (kadar debu total, kadar karbon monoksida, dan faktor individu responden). Pengukuran gambaran faal paru menggunakan alat spirometer Pony Fx dan dilakukan oleh petugas laboratorium IKM Unnes. Waktu pengukuran spirometry dilakukan pada saat pergantian shift kerja pagi dan shift kerja siang di tiap lokasi SPBU. Sedangkan, pengukuran kadar debu total menggunakan alat High Volume Sampler (HVS) Staplex TFIA-2 dan pengukuran juga dilakukan oleh petugas laboratorium Unnes selama 2 jam pengukuran di tiap SPBU dengan prinsip gravimetri. Kemudian kadar karbon monoksida diukur menggunakan alat $\mathrm{CO}$ digital dan pengukuran dilakukan oleh petugas laboratorium Teknik Lingkungan Undip. Hasil pengukuran kadar CO merupakan hasil rata-rata dari pengukuran di 5 titik pengukuran di setiap lokasi SPBU. Variabel faktor individu diukur menggunakan kuesioner dari American Thoracic Society (ATS) dan kuesioner individu Riskesdas dengan teknik wawancara.

\section{HASIL DAN PEMBAHASAN}

Analisis univariat dilakukan untuk mengetahui gambaran distribusi dan presentase dari tiap variabel. Hasil analisis univariat pada penelitian ini tersaji pada tabel 1 .

Pada tabel 1 terlihat bahwa sebagian besar umur responden yaitu $<30$ tahun $(73,5 \%)$ dan berjenis kelamin laki-laki. Sebanyak $61,8 \%$ responden memiliki masa kerja $<5$ tahun dan 
Tabel 1. Hasil Analisis Univariat

\begin{tabular}{lllcc}
\hline No. & Variabel & Kategorik & Jumlah & Presentase (\%) \\
\hline 1. & Umur & $\geq 30$ tahun & 9 & 26,5 \\
& & $<30$ tahun & 25 & 73,5 \\
2. & \multirow{2}{*}{ Jenis Kelamin } & Perempuan & 7 & 20,6 \\
& & Laki-laki & 27 & 79,4 \\
3. & Masa Kerja & $\geq 5$ tahun & 13 & 38,2 \\
& & $<5$ tahun & 21 & 61,8 \\
4. & Lama Paparan & $>8$ jam & 7 & 20,6 \\
& & $\leq 8$ jam & 27 & 79,4 \\
5. & \multirow{2}{*}{ Kebiasaan Merokok } & Merokok & 10 & 29,4 \\
& & Tidak Merokok & 24 & 70,6 \\
6. & \multirow{2}{*}{ Penggunaan APD } & Tidak & 29 & 85,3 \\
& & Ya & 5 & 14,7 \\
7. & \multirow{2}{*}{ Status Gizi } & Tidak Normal & 14 & 41,2 \\
& & Normal & 20 & 58,8 \\
8. & \multirow{2}{*}{ Riwayat Penyakit } & Ada riwayat & 3 & 8,8 \\
& & Tidak ada riwayat & 31 & 91,2 \\
9. & \multirow{2}{*}{ Gambaran Faal Paru } & Normal & 18 & 52,9 \\
& & Tidak Normal & 16 & 47,1 \\
\hline
\end{tabular}

$79,4 \%$ responden memiliki lama paparan $\leq 8$ jam per hari. Banyak dari responden yang tidak memiliki perilaku merokok namun dalam hal penggunaan APD sebagian besar responden tidak memakai APD atau masker ketika bekerja. Sebanyak $58,8 \%$ responden memiliki status gizi normal yang dilihat dari nilai IMT dan 91,2\% responden mengaku tidak memiliki riwayat penyakit pernapasan.

Pengukuran spirometri untuk mengetahui gambaran faal paru pada responden dilakukan di dua lokasi SPBU. Waktu pengukuran dilakukan pada saat pergantian shift kerja pagi dan siang yang berjumlah 17 orang pada tiap SPBU. Pengukuran dilakukan oleh petugas laboratorium dengan menggunakan alat Spirometer Pony FX. Hasil pengukuran spirometri menunjukkan bahwa 16 responden atau $47,1 \%$ memiliki gambaran faal paru tidak normal dan 18 responden atau 52,9\% memiliki gambaran faal paru normal.

Hasil analisis univarat dari kadar debu total di lokasi penelitian dan kadar karbon monoksida menunjukkan masih di bawah nilai ambang batas yang ditetapkan sehingga masih tergolong ke kategori normal. Hasil pengukuran kadar debu menggunakan alat HVS selama 2 jam pengukuran dan karbon monoksida menggunakan alat $\mathrm{CO}$ digital di lingkungan SPBU terlihat pada tabel 2.
Hasil penelitian diperoleh bahwa petugas SPBU bekerja di lingkungan yang memeiliki kadar debu rata-rata sebesar $1,074 \mathrm{mg} / \mathrm{m}^{3}$, dengan nilai minimal $0,96 \mathrm{mg} / \mathrm{m}^{3}$ dan maksimal $1,188 \mathrm{mg} / \mathrm{m}^{3}$, serta standar deviasi 0,019 $\mathrm{mg} / \mathrm{m}^{3}$.

Berdasarkan Permenaker No.13/MEN/2011 tentang nilai ambang batas faktor fisika dan faktor kimia ditempat kerja, batas paparan partikulat adalah $10 \mathrm{mg} / \mathrm{m}^{3}$, sehingga kadar debu di lokasi SPBU masih memenuhi nilai ambang batas.

Hasil pengukuran kadar $\mathrm{CO}$ rata-rata $1,384 \mathrm{mg} / \mathrm{m}^{3}$ dengan nilai minimal $0,56 \mathrm{mg} / \mathrm{m}^{3}$ dan maksimal $25,65 \mathrm{mg} / \mathrm{m}^{3}$, serta standar deviasi $1,271 \mathrm{mg} / \mathrm{m}^{3}$. Berdasarkan Permenaker No.13/MEN/2011 tentang nilai ambang batas faktor fisika dan faktor kimia ditempat kerja, batas paparan karbon monoksida (CO) adalah $29 \mathrm{mg} / \mathrm{m}^{3}$, sehingga kadar CO di lokasi SPBU masih memenuhi nilai ambang batas.

Analisis bivariat dilakukan pada penelitian ii untuk mengetahui hubungan antara variabel bebas dan variabel terikat. Hasil analisis hubungan antara faktor individu yang berupa umur, jenis kelamin, masa kerja, lama paparan, kebiasaan merokok, penggunaan APD, status gizi, dan riwayat penyakit dengan gambaran faal paru petugas SPBU tersaji pada tabel 3. 
Tabel 2. Hasil Pengukuran Kadar Debu Total dan Kadar CO di Lokasi SPBU

\begin{tabular}{llllll}
\hline No. & Lokasi & $\begin{array}{l}\text { Kadar Debu } \\
\left(\mathrm{mg} / \mathrm{m}^{3}\right)\end{array}$ & Keterangan & $\begin{array}{l}\text { Kadar CO } \\
\left(\mathrm{mg} / \mathrm{m}^{3}\right)\end{array}$ & Keterangan \\
\hline 1. & SPBU 1 & 0,96 & $\begin{array}{l}\text { memenuhi } \\
\text { NAB }\end{array}$ & 0,56 & $\begin{array}{l}\text { memenuhi } \\
\text { NAB } \\
\text { memenuhi }\end{array}$ \\
2. & SPBU 2 & 1,188 & NAB & 25,65 & NAB \\
\hline & Mean & 1,074 & & 1,384 & \\
SD & 0,019 & & 1,271 & \\
Min & 0,96 & & 0,56 & \\
Max & 1,188 & & 25,65 & \\
\hline
\end{tabular}

Tabel 3. Hubungan antara Faktor Individu dengan Gambaran Faal Paru

\begin{tabular}{|c|c|c|c|c|c|c|c|c|c|}
\hline \multirow{3}{*}{ No. } & \multirow{3}{*}{ Variabel } & \multirow{3}{*}{ Kategori } & \multicolumn{6}{|c|}{ Gambaran Faal Paru } & \multirow{3}{*}{$p$ value } \\
\hline & & & \multicolumn{2}{|c|}{$\begin{array}{c}\text { Tidak } \\
\text { Normal }\end{array}$} & \multicolumn{2}{|c|}{ Normal } & \multicolumn{2}{|c|}{ Total } & \\
\hline & & & $\mathrm{n}$ & $\%$ & $\mathrm{n}$ & $\%$ & $\mathrm{n}$ & $\%$ & \\
\hline \multirow[t]{2}{*}{1.} & \multirow[t]{2}{*}{ Umur } & $\geq 30$ tahun & 4 & 44,4 & 5 & 55,6 & 9 & 100,0 & 1,000 \\
\hline & & $<30$ tahun & 12 & 48,0 & 13 & 52,0 & 25 & 100,0 & \\
\hline \multirow[t]{2}{*}{2.} & \multirow[t]{2}{*}{ Jenis Kelamin } & Perempuan & 6 & 85,7 & 1 & 14,3 & 7 & 100,0 & 0,035 \\
\hline & & Laki-laki & 10 & 37,1 & 17 & 62,9 & 27 & 100,0 & \\
\hline \multirow[t]{2}{*}{3.} & \multirow[t]{2}{*}{ Masa Kerja } & $\geq 5$ tahun & 10 & 76,9 & 3 & 23,1 & 13 & 100,0 & 0,017 \\
\hline & & $<5$ tahun & 6 & 28,6 & 15 & 71,4 & 21 & 100,0 & \\
\hline \multirow[t]{2}{*}{4.} & \multirow[t]{2}{*}{ Lama Paparan } & $>8$ jam & 4 & 57,1 & 3 & 42,9 & 7 & 100,0 & 0,681 \\
\hline & & $\leq 8 \mathrm{jam}$ & 12 & 44,4 & 15 & 55,6 & 27 & 100,0 & \\
\hline \multirow[t]{2}{*}{5.} & \multirow{2}{*}{$\begin{array}{l}\text { Kebiasaan } \\
\text { merokok }\end{array}$} & Merokok & 8 & 80,0 & 2 & 20,0 & 10 & 100,0 & 0,023 \\
\hline & & $\begin{array}{l}\text { Tidak } \\
\text { Merokok }\end{array}$ & 8 & 33,3 & 16 & 66,7 & 24 & 100,0 & \\
\hline \multirow[t]{2}{*}{6.} & \multirow[t]{2}{*}{$\begin{array}{l}\text { Penggunaan } \\
\text { APD }\end{array}$} & $\begin{array}{l}\text { Tidak pakai } \\
\text { APD }\end{array}$ & 14 & 48,3 & 15 & 51,7 & 29 & 100,0 & 1,000 \\
\hline & & Pakai APD & 2 & 40,0 & 3 & 60,0 & 5 & 100,0 & \\
\hline \multirow[t]{2}{*}{7.} & \multirow[t]{2}{*}{ Status Gizi } & $\begin{array}{l}\text { Tidak } \\
\text { Normal }\end{array}$ & 4 & 28,6 & 10 & 71,4 & 14 & 100,0 & 0,145 \\
\hline & & Normal & 12 & 60,0 & 8 & 40,0 & 20 & 100,0 & \\
\hline \multirow[t]{2}{*}{8.} & \multirow{2}{*}{$\begin{array}{l}\text { Riwayat } \\
\text { Penyakit }\end{array}$} & Ada riwayat & 2 & 66,7 & 1 & 33,3 & 3 & 100,0 & 0,591 \\
\hline & & $\begin{array}{l}\text { Tidak ada } \\
\text { riwayat }\end{array}$ & 14 & 45,2 & 17 & 54,8 & 31 & 100,0 & \\
\hline
\end{tabular}

Hasil analisis hubungan antara umur dengan gambaran faal paru menggunakan uji statistik diperoleh nilai $p$ sebesar $1,000(p>0,05)$, sehingga dapat disimpulkan bahwa tidak ada hubungan antara umur dengan gambaran faal paru pada petugas SPBU.

Hasil penelitian ini tidak sesuai dengan teori bahwa secara fisiologis menurunnya kapasitas vital paru yaitu setelah menginjak umur 40 tahun dan terus menurun seiring bertambahnya umur. Pertambahan usia serta pada penderita penyakit paru kronis, maka sebagian daya elastisitas paru hilang. Akibatnya, penutupan saluran udara dapat terjadi dan menurunkan volume paru (Ganong, 2002). Hasil ini sejalan dengan penelitian yang dilakukan oleh Ginting (2015) bahwa tidak ada hubungan antara umur dengan gambaran faal paru dengan nilai $p=0,805$. Hasil penelitian ini tidak sejalan dengan penelitian Aulia (2010) tentang faktor-faktor yang berhubungan dengan kapasitas vital paru pada operator SPBU bahwa 
ada hubungan antara umur dengan kapasitas vital paru dengan nilai $p=0,036$.

Hasil analisis hubungan antara jenis kelamin dengan gambaran faal paru menggunakan uji statistik diperoleh nilai $p$ sebesar $0,035 \quad(p<0,05), \quad$ sehingga dapat disimpulkan bahwa ada hubungan antara jenis kelamin dengan gambaran faal paru pada petugas SPBU. Hasil ini sesuai dengan teori yang menyatakan bahwa kebutuhan oksigen pada laki-laki lebih besar karena energi yang dibutuhkan lebih besar dibandingkan dengan perempuan. Volume dan kapasitas seluruh paru pada wanita kira-kira 20 sampai $25 \%$ lebih kecil dibandingkan laki-laki. Hasil ini sejalan dengan penelitian yang dilakukan oleh Aulia (2010) yang menyatakan bahwa ada hubungan yang signifikan antara jenis kelamin dengan kapasitas vital paru pada operator SPBU. Berdasarkan hasil penelitian ini diketahui bahwa perempuan berisiko 10,2 kali lebih besar memiliki gambaran faal paru tidak normal dibandingkan dengan laki-laki. Penelitian menunjukkan bahwa lakilaki lebih berisiko memiliki gangguan asma dibandingkan dengan perempuan. Namun, seiring pertumbuhan pada masa remaja terjadi perubahan dimana perempuan memiliki risiko lebih tinggi terkena asma dibandingkan dengan laki-laki. Perubahan ini dipengaruhi oleh adanya perubahan hornmonal pada perempuan (Almqvist, 2008). Ketika wanita mengalami periode menstruasi, fluktuasi kadar hormon reproduksi menyebabkan penurunan kadar hormon insulin di dalam tubuh akibatnya kadar gula darah meningkat. Resistensi insulin dapat merusak produksi adenosin triphosphate mitokondria yang menyebabkan berkurangnya kekuatan otot termasuk otot pernapasan. Proses respirasi membutuhkan kontraksi otot untuk mengatasi tekanan udara pada area dada. Kelemahan otot pernapasan dapat mengakibatkan gangguan fungsi ventilasi paruparu (Kim, 2010).

Hasil analisis hubungan antara masa kerja dengan gambaran faal paru menggunakan uji statistik menunjukkan bahwa ada hubungan antara masa kerja dengan gambaran faal paru pada petugas SPBU dengan nilai $p=0,017$. Hasil ini menunjukkan bahwa seseorang dengan masa kerja $\geq 5$ tahun berisiko 8,3 kali lebih besar memiliki gambaran faal paru tidak normal dibandingkan dengan seseorang dengan masa kerja $<5$ tahun. Hasil ini sesuai dengan teori yang menyatakan bahwa pekerja yang bekerja di lingkungan kerja dengan kadar pencemar yang tinggi dalam waktu yang lama memiliki risiko terkena obstruksi paru. Paparan partikel 1-2 $\mathrm{mg} / \mathrm{m}^{3}$ dapat menyebabkan penyakit yang terdeteksi dalam 5-15 tahun. Masa kerja yang terlalu lama menjadikan jumlah partikel yang mengendap dalam tubuh pekerja juga akan semakin banyak. Hasil penelitian ini sesuai dengan penelitian Dase (2013) bahwa ada hubungan yang bermakna antara masa kerja dengan kapasitas paru pada petugas SPBU di Makasar dengan nilai $p=0,019$. Hasil ini juga diperkuat dengan hasil penelitian Aulia (2013) bahwa ada hubungan antara masa kerja dengan kapsitas paru dengan nilai $p=0,019$. Hasil penelitian Setiawan (2011) juga menunjukkan bahwa ada hubungan antara masa kerja dengan kapasitas vital paru operator SPBU di Yogyakarta dengan nilai $p=0,018$.

Hasil analisis hubungan antara lama paparan dengan gambaran faal paru menggunakan uji statistik menunjukkan bahwa tidak ada hubungan antara lama paparan dengan gambaran faal paru pada ptugas SPBU dengan nilai $p=0,681$. Hasil ini tidak sejalan dengan teori yang menyatakan bahwa semakin lama paparan maka semakin banyak terpapar bahaya yang ditmbulkan oleh lingkungan kerja tersebut. Menurut UU No. 13 Tahun 2003 tentang Ketenagakerjaan waktu kerja normal yaitu 7 sampai 8 jam dalam sehari. Apabila waktu kerja lebih dari waktu yang telah ditentukan maka akan terlihat penurunan produktivitas serta kecenderungan timbulnya kelelahan, penyakit, dan kecelakaan (Suma'mur, 1996). Hasil penelitian ini bertentangan dengan penelitian Febrianto (2015) yang menyatakan bahwa ada hubungan antara lama paparan dengan gangguan faal paru dengan nilai $p=0,006$.

Hasil analisis hubungan antara kebiasaan merokok dengan gambaran faal paru 
menggunakan uji statistik menunjukkan bahwa ada hubungan antara kebiasaan merokok dengan gambaran faal paru pada petugas SPBU dengan nilai $p=0,023$. Hasil ini sejalan dengan teori yang menyatakan bahwa kebiasaan merokok dapat menurunkan kapasitas vital paru. Zat toksin yang ada dalam rokok akan terakumulasi jumlahnya di dalam tubuh terutama dalam paru-paru. Keberadaan zat toksin ini akan menghambat proses pertukaran $\mathrm{O}_{2}$ dan $\mathrm{CO}_{2}$ di dalam alveolus. Hal ini akan mengurangi jumlah alveolus fungsional yang berperan dalam respirasi yang mengakibatkan penurunan fungsi dari organ paru-paru (Stampfli, 2009). Hasil penelitian Dase (2013) juga menyatakan bahwa ada hubungan antara kebiasaan merokok dengan gangguan kapasitas paru dengan nilai $p=0,019$. Menurut hasil penelitian ini bahwa seseorang yang merokok berisiko 8 kali lebih besar memiliki gambaran faal paru tidak normal dibandingkan dengan seseorang yang tidak merokok.

Hasil analisis hubungan antara penggunaan APD dengan gambaran faal paru menggunakan uji statistik menunjukkan bahwa tidak ada hubungan antara penggunaan APD dengan gambaran faal paru pada petugas SPBU dengan nilai $p=1,000$. Penggunaan APD merupakan salah satu upaya untuk mencegah terjadinya penyakit akibat kerja. Hasil penelitian ini tidak sejalan dengan penelitian Esha (2017) bahwa ada hubungan antara penggunaan masker dengan kapasitas vital paru pada petugas parkir dengan nilai $p=0,005$ dan penelitian Khumaidah (2009) juga menyatakan bahwa ada hubungan antara penggunaan APD dengan kapasitas vital paru dengan nilai $p=0,005$. Namun hasil penelitian ini sejalan dengan penelitian Ginting (2015) yang menyatakan bahwa tidak ada hubungan antara penggunaan APD $(p=0,557)$ dengan penurunan faal paru pada polisi lalu lintas. Hasil penelitan Handani (2018) juga menyatakan bahwa tidak ada hubungan antara penggunaan APD $(p=1,000)$ dengan gangguan fungsi paru.

Hasil analisis hubungan antara status gizi dengan gambaran faal paru pada petugas SPBU menggunakan uji statistik menunjukkan bahwa tidak ada hubungan antara status gizi dengan gambaran faal paru pada petugas SPBU dengan nilai $p=0,145$. Hasil penelitian ini tidak sesuai dengan teori bahwa berat badan rendah berhubungan dengan penurunan kekuatan otot respirasi. Sedangkan, berat badan berlebih atau obesitas memberikan beban tambahan pada thoraks dan abdomen berupa pembatasan pergerakan dinding dada dan diafragma, sehingga menyebabkan kekakuan dan berkurangnya compliance (daya kembang) paru. Seseorang dengan berat badan berlebih (obesitas) menunjukkan penuruan volume paruparu dibandingkan dengan seseorang yang sehat. Biasanya penuruan dari kapasitas total paru disertai dengan penurunan FEV1 (Melo, 2014). Hasil penelitian ini sejalan dengan penelitian Aulia (2010) bahwa tidak ada hubungan antara status gizi $(p=1,000)$ dengan kapasitas vital paru pada operator SPBU di Palembang. Hasil ini juga diperkuat dengan hasil penelitian Dase (2013) bahwa tidak ada hubungan antara status gizi dengan kapasitas paru pada operator SPBU di Makasar dengan nilai $p=0,920$.

Hasil analisis hubungan antara riwayat penyakit dengan gambaran faal paru menggunakan uji statistik menunjukkan bahwa tidak ada hubungan antara riwayat penyakit dengan gambaran faal paru pada petugas SPBU dengan nilai $p=0,591$. Hasil ini tidak sejalan dengan teori yang menyatakan bahwa kondisi kesehatan dapat mempengaruhi kapasitas vital paru seseorang dan kekuatan otot-otot pernapasan dapat berkurang akibat sakit. Seseorang yang pernah mengidap penyakit paru akan mengurangi ventilasi perfusi sehingga alveolus akan sedikit mengalami pertukaran udara dan mengakibatkan menurunnya kadar oksigen dalam darah (Ganong, 2002). Hasil penelitian ini sejalan dengan penelitian Aulia (2010) bahwa tidak ada hubungan antara riwayat penyakit dengan kapasitas vital paru pada operator SPBU dengan nilai $p=0,656$.

Hasil analisis hubungan antara paparan debu dan karbon monoksida dengan gambaran faal paru pada petugas SPBU menggunakan uji statistik Mann Whietney disajikan pada tabel 4. 
Tabel 4. Hubungan antara Paparan debu dan Karbon Monoksida dengan Gambaran Faal Paru

\begin{tabular}{lllll}
\hline \multirow{2}{*}{ No. } & Variabel & \multicolumn{2}{l}{ Gambaran Faal Paru } & Normal \\
\cline { 2 - 4 } & $\begin{array}{l}\text { Tidak } \\
\text { Normal }\end{array}$ & 0,498 \\
\hline 1. & $\begin{array}{l}\text { Paparan Debu } \\
\left(\mathrm{mg} / \mathrm{m}^{3} ; \text { median(min-maks) }\right)\end{array}$ & $1,188(0,96-1,188)$ & $0,96(0,96-1,188)$ & 0,498 \\
2. & $\begin{array}{l}\text { Paparan CO } \\
\left(\mathrm{mg} / \mathrm{m}^{3} ; \text { median(min-maks) }\right)\end{array}$ & $2,56(0,56-25,65)$ & $1,31(0,58-25,65)$ & 0,720 \\
\hline
\end{tabular}

Berdasarkan hasil analisis hubungan antara paparan debu dengan gambaran faal paru pada petugas SPBU menggunakan uji statistik Mann Whitney menunjukkan bahwa tidak ada hubungan antara paparan debu dengan gambaran faal paru pada petugas SPBU dengan nilai $\mathrm{p}=0,498$. Hasil analisis hubungan antara paparan karbon monoksidaa dengan gambaran faal paru juga menunjukkan bahwa tidak ada hubungan antara paparan karbon monoksida $(p=0,720)$ dengan gambaran faal paru pada petugas SPBU.

Menurut hasil pengukuran kadar debu total di lokasi penelitian menggunakan alat HVS Staplex TFIA-2 selama 2 jam pengukuran menunjukkan bahwa kadar debu total di kedua SPBU masih dibawah nilai ambang batas yaitu sebesar $0,96 \mathrm{mg} / \mathrm{m}^{3}$ dan $1,188 \mathrm{mg} / \mathrm{m}^{3}$ menurut Permenaker No. 13 Tahun 2011 tentang Nilai Ambang Batas Faktor Fisika dan Faktor Kimia di Tempat Kerja yaitu sebesar $10 \mathrm{mg} / \mathrm{m}^{3}$. Sedangkan, hasil pengukuran kadar CO menggunakan CO Digital menunjukkan bahwa kadar CO di kedua SPBU masih dibawah nilai ambang batas sebesar $0,56 \mathrm{mg} / \mathrm{m}^{3}$ dan 25,65 $\mathrm{mg} / \mathrm{m}^{3}$ menurut Permenaker No. 13 Tahun 2011 tentang Nilai Ambang Batas Faktor Fisika dan Faktor Kimia di Tempat Kerja yaitu sebesar $29 \mathrm{mg} / \mathrm{m}^{3}$.

Berdasarkan hasil wawancara dengan petugas SPBU terdapat beberapa keluhan yang dirasakan ketika bekerja seperti batuk, sesak napas, hingga pusing. Hasil spirometri menunjukkan gambaran faal paru yang tidak normal pada responden yang mengalami keluhan tersebut. Menurut Suyono (1995) paparan partikel $1-2 \mathrm{mg} / \mathrm{m}^{3}$ dapat menyebabkan penyakit yang terdeteksi dalam 5-15 tahun. Pada paparan yang lebih rendah penyakit berkembang lebih lama dan gejala sering kali tidak tampak hingga setelah berhentinya paparan. Sedangkan, kontak dengan $\mathrm{CO}$ pada konsentrasi tinggi dapat menyebabkan kematian, tetapi kontak dengan $\mathrm{CO}$ pada konsentrasi relatif rendah dapat mengganggu kesehatan. Hasil penelitian Lippmann (2009) menunjukkan bahwa ada peningkatan keluhan sesak napas sebesar $10 \%$ yang disebabkan oleh paparan debu dari kendaraan bermotor. Hasil penelitian Damri (2016) menunjukkan bahwa CO menyebabkan rasa sakit yang dirasakan oleh petugas parkir dan semakin tinggi konsentrasi paparan CO maka akan semakin kuat pula rasa sakit yang diderita oleh petugas parkir dalam bekerja.

Hubungan antara paparan dan efek tergantung dengan lamanya paparan. Semakin lama paparan semakin banyak terpapar bahaya yang ditimbulkan oleh lingkungan kerja tersebut (Suyono, 1995). Terdapat 21 responden $(61,8 \%)$ memiliki masa kerja $<5$ tahun dan 27 responden $(79,4 \%)$ memiliki lama paparan per hari $\leq 8$ jam. Diberlakukan pula sistem kerja shift sehingga tingkat paparan yang diterima tiap responden berbeda dan mempengaruhi tingkat keluhan yang dirasakan.

Hasil analisis multivariat dengan menggunakan uji Regresi Logistik untuk mengetahui faktor yang paling berhubungan dengan gambaran faal paru pada petugas SPBU disajikan pada tabel 5 .

Hasil analisis multivariat menunjukkan terdapat 3 variabel yang paling berhubungan dengan gambaran faal paru pada petugas SPBU yaitu jenis kelamin dengan rasio prevalensi $0,010$ (CI $95 \%=0,000-0,222)$, masa kerja $(\geq 5$ tahun) dengan rasio prevalensi 0,068 (CI 95\% = $0,006-0,808)$, dan kebiasaan merokok dengan 
Tabel 5. Hasil Analisis Multivariat dengan Regresi Logistik

\begin{tabular}{|c|c|c|c|c|c|}
\hline No. & Variabel & Wald & $p$ value & OR & $95 \% \mathrm{CI}$ \\
\hline 1. & Jenis Kelamin & 8,426 & 0,004 & 0,010 & $0,000-0,222$ \\
\hline 2. & Masa Kerja & 4,530 & 0,033 & 0,068 & $0,006-0,808$ \\
\hline 3. & Kebiasaan Merokok & 5,926 & 0,015 & 0,042 & $0,003-0,540$ \\
\hline
\end{tabular}

rasio prevalensi 0,042 (CI 95\% $=0,003-0,540)$. Dari ketiga variabel tersebut, variabel yang paling berhubungan dengan gambaran faal paru yaitu variabel jenis kelamin. Hal ini dikarenakan variabel jenis kelamin memiliki nilai p yang paling kecil yaitu 0,004 dan nilai Wald yang paling besar yaitu 8,426 . Dapat disimpulkan bahwa setelah mengontrol variabel lain, seseorang yang berjenis kelamin perempuan berisiko 0,010 kali lebih besar memiliki gambaran faal paru tidak normal dibandingkan dengan seseorang yang berjenis kelamin laki-laki.

\section{PENUTUP}

Berdasarkan hasil penelitian mengenai hubungan antara faktor individu, paparan debu, dan karbon monoksida dengan gambaran faal paru pada petugas SPBU menunjukkan bahwa ada hubungan antara jenis kelamin, masa kerja, dan kebiasaan merokok dengan gambaran faal paru pada petugas SPBU. Sedangkan, tidak ada hubungan yang bermakna antara umur, lama paparan, penggunaan APD, status gizi, dan riwayat penyakit dengan gambaran faal paru pada petugas SPBU. Hasil analisis multivariat menunjukkan bahwa faktor jenis kelamin merupakan faktor yang paling berhubungan dengan gambaran faal paru pada petugas SPBU pada penelitian ini.

Bagi peneliti selanjutnya, hasil penelitian ini dapat dijadikan sebagai acuan dan diharapkan untuk menggunakan desain penelitian lainnya untuk memperkuat hasil dan untuk melihat hubungan sebab akibat antara variabel bebas dan variabel terikat.

\section{DAFTAR PUSTAKA}

Aulia, AS. C. P, Hasyim, H., dan Purba, I.G. 2010. Faktor-Faktor yang Berhubungan dengan Kapasitas Vital Paru pada Operator SPBU 24.301.118 Palembang 2010. Jurnal Ilmu Kesehatan Masyarakat, 1, pp. 217-224.

Almqvist, C., Worm, M., dan Leynaert, B. 2008. Impact Of Gender On Asthma In Childhood And Adolescence: A GA 2LEN Review. Allergy: European Journal of Allergy and Clinical Immunology, 63(1), 47-57.

Anggarani, D.N., Rahardjo, M., dan Murjazuli. 2016. Hubungan Kepadatan Lalu Lintas dengan Konsentrasi $\mathrm{COHb}$ pada Masyarakat Berisiko Tinggi di Sepanjang Jalan Nasional Kota Semarang. Jurnal Kesehatan Masyarakat, 4(2), 139-148.

Damri, Ilza M., dan Afandi, D. 2016. Analsis Paparan $\mathrm{CO}$ dan $\mathrm{SO}_{2}$ pada Petugas Parkir di Basement Mall Ska di Kota Pekanbaru. Dinamika Lingkungan Indonesia, 3(1), pp. 4856.

Dase, T., Russeng, S.S., dan Muis, M. 2013. Faktor yang Berhubungan dengan Kapasitas Paru pada Karyawan SPBU Pasti Pas! di Kecamatan Tamalanrea Kota Makassar. Jurnal UNHAS, 3(1), 1-8.

Esha, I., Afandi, D., dan Amrifo, V. 2017. Analisis Paparan Gas Polutan Karbon Monoksida terhadap Fungsi Paru Petugas Parkir di Ruang Bawah Tanah Mal X Kota Pekanbaru. Jurnal Ilmu Lingkungan, 11(1), 25-34.

Febrianto, A.A., Sujono, A.D.P., dan Hartanti, R.I. 2015. Hubungan antara Karakteristik Individu, Paparan Debu Asap Las (Welding Fume) dan gas Karbon Monoksida dengan Gangguan Faal Paru pada Pekerja Bengkel Las. E-Journal Pustaka Kesehatan, 3(3), pp. 515521.

Ganong, W.F. 2002. Buku Ajar Fisiologi Kedokteran $20^{\text {th }} e d n$. Jakarta: EGC.

Ginting, M., Yunus, F., dan Antariksa, B. 2015. Faal Paru pada Polisi Lalu Lintas Jakarta Pusat 
dan Faktor-Faktor yang Mempengaruhi. $J$ Respir Indo, 35(2), pp. 97-106.

Handari, M.C., Sugiharto, S. and Pawenang, E.T., 2018. Karakteristik Pekerja dengan Kejadian Gangguan Fungsi Paru pada Pekerja Dipo Lokomotif. HIGEIA (Journal of Public Health Research and Development), 2(1), pp.45-56.

Kim, H. J, Lee ,J. Y., Jung, H.S., Lee, S.M., Yim, J.J., Yoo, C.G., Chung, H.S., Kim, Y.W., Han, S.K., Shim, Y.S., C. H. L. 2010. The Impact of Insulin Sensitisers on Lung Function in Patients with Chronic Obstructive Pulmonary Disease and Diabetes. INT $J$ Tuberc Lung Dis, 14(3), 362-267.

Khumaidah. 2009. Analisis Faktor yang Berhubungan dengan Gangguan Fungsi Paru pada pekerja Mebel PT. Kota Jati Furindo Desa Suwawal Kabupaten Jepara. Tesis. Semarang: Universitas Diponegoro.

Lippmann, M., and Chen, L.C. 2009. Effects of Metals within Ambient Air Particulate Metter (PM) on Human Health. Journal of Inhalation Toxicology, 21(1), 1-31.

Melo, L.C., Silva, M.A.M., and Calles, A.C.N. 2014. Obesity and Lung Function: a Systematic Review. Journal Einstein, 12(1), 120-125.
Obaseki, D., Adeniyi, B., Jumbo, J., Oyewo, A., Irabor, I., and Enhabor, G.E. 2014. Respiratory Symptom, Lung Function and Exhaled Carbon Monoxide Among a Sample of Traffic Workers in Lagos, Nigeria: a Pilot Survey. Nigerian Medical Journal, 55(4), pp. 306-309.

Santos, U.P., Garcia, M.L.S.B., Braga, A.L.F., Pereira, L.A.A., Lin, C.A., Andre, P.A.D., Andre, C.D.S., Singer, J.M., and Saldiva, P.H.N. 2016. Assosiation Between Traffic Air Pollution and Reduced Forced Vital Capacity: a Study Using Personal Monitors for Outdoor Workers. Plos ONE, 11(10), pp. 1-12.

Setiawan, I., dan Haryono, W. 2011. Hubungan Masa Kerja dengan kapasitas Vital Paru Operator Empat Stasiun Pengisian Bahan Bakar Umum (SPBU) Kota Yogyakarta. Kesmas, 5(3), pp. 162-232.

Stampfli, M.R., and Anderson, G.P. 2009. How Cigarette Smoke Immune Responses to Promote Infection, Lung Disease and Cancer. Nature Review Immunology, 9(5), pp377-384.

Suma'mur. 1996. Higene Perusahaan dan Keselamatan Kerja. Jakarta: CV. Haji Masagung.

Suyono, J. 1995. Deteksi Dini Penyakit Akibat Kerja. Jakarta: EGC. 